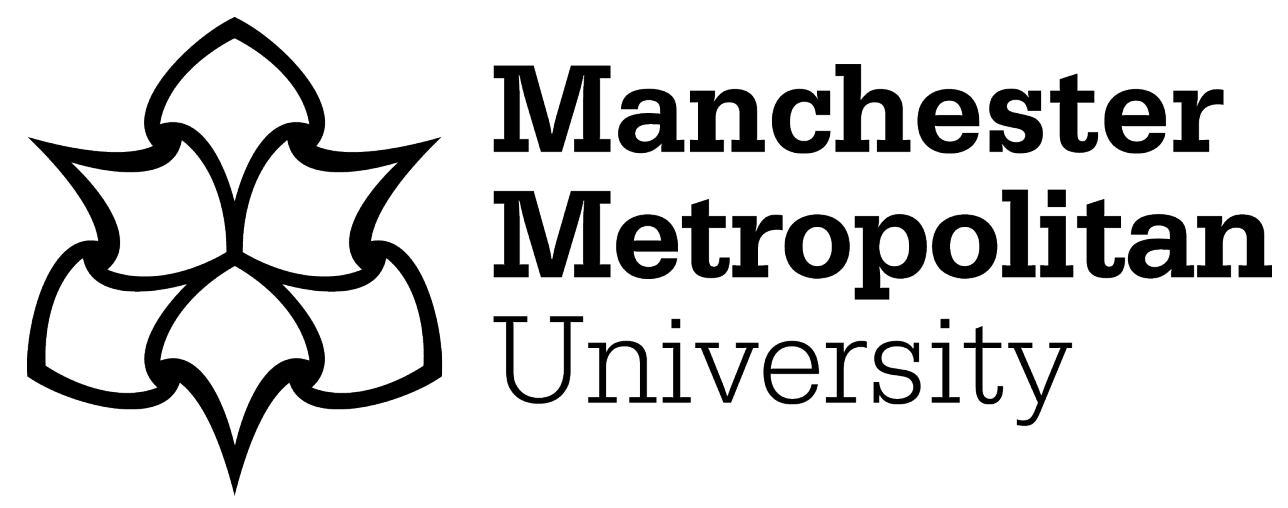

Walmsley, A, Partington, S ORCID logoORCID: https://orcid.org/0000-00025001-1416, Armstrong, R and Goodwin, H (2019) Reactions to the National Living Wage in Hospitality. Employee Relations, 41 (1). pp. 253-268. ISSN 0142-5455

Downloaded from: https://e-space.mmu.ac.uk/623178/

Version: Accepted Version

Publisher: Emerald

DOI: https://doi.org/10.1108/ER-02-2018-0044

Please cite the published version 


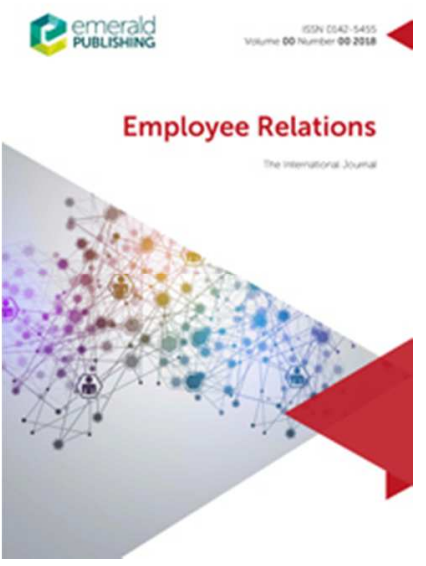

\section{Reactions to the national living wage in hospitality}

\begin{tabular}{|r|l|}
\hline Journal: & Employee Relations \\
\hline Manuscript ID & ER-02-2018-0044.R2 \\
\hline Manuscript Type: & Research Paper \\
\hline Keywords: & $\begin{array}{l}\text { Hospitality, National Living Wage, Minimum wage, Employee relations, } \\
\text { Living Wage, Low Pay }\end{array}$ \\
\hline \multicolumn{2}{|l}{} \\
\hline
\end{tabular}

SCHOLARONE ${ }^{m}$

Manuscripts 


\section{Reactions to the national living wage in hospitality}

Purpose: To explore reactions to the introduction by the UK Government of the National Living Wage in the UK hospitality sector and consider implications for the status of employee relations. Design/methodology/approach: In-depth interviews were conducted with senior industry representatives of the hospitality sector in the UK.

Findings: Concerns surrounding an increase in the wage bill, in maintaining pay differentials and in shifting employment to youth were confirmed. Managers expressed ambiguity in face of the legislation, offering agreement at a personal level with the rationale underpinning the NLW, but also expressing concern about impacts on their businesses.

Research limitations/implications: This exploratory study offers the basis for further research in understanding the foundation of employee relations in hospitality.

Social implications: A reconsideration of the nature of the employment relationship is key at a time of growing concerns about the business-society relationship.

Originality/value: Uses reactions to the UK Government's stipulation of a national living wage to explore the basis of employee relations in the hospitality sector. This is timely where work to date in hospitality has largely focussed on symptoms but not causes of poor working conditions.

\section{Introduction}

Disquiet surrounding low wages is not new (Brown, 2017, notes the establishment of wage councils in 1909 as concerns over childhood poverty mounted). Referring to low wages in the 1970s, Pond (1983) concluded that low pay, once again, had become a matter of central importance in industrial relations. Today, arguably, low wages are yet again an issue that has not gone away ( $D^{\prime} A r c y, 2017$ ) and continues to assume central importance in industrial relations (Prowse \& Fells, 2016).

This study focuses on the hospitality industry because of its ongoing concern with the employment relationship generally, and because it is widely acknowledged as a low wage sector specifically. The sector is large, diverse and continues to witness ongoing changes, growth in many areas (e.g. the rise of the budget hotel sector, the rise of boutique hotels and the expansion of international hotel chains) and sharp decline in others (e.g. public house/licensed bars and very recently consolidation in a number of restaurant chains). It includes major international hotel and restaurant chains, but 
equally a large proportion of businesses in the sector are not only small, but micro enterprises (employing fewer than ten employees).

The sector, at its simplest, is defined as covering the provision of accommodation, food and drink outside the home (Jones, 2002). As such, it includes numerous sub-sectors such as hotels, youth hostels, holiday centres and villages, licensed restaurants, unlicensed restaurants and cafes and event catering activities (see for further details the Standard Industrial Classification of economic activities). Because of the broad scope of hospitality as an economic activity, and with a view to seeking some degree of uniformity in the businesses reviewed, it was decided to focus in this study solely on hotels as one of hospitality's key subsectors.

The industry in which people work has a significant bearing on their risks of being low paid. . Data from the Office for National Statistics (2016) indicate that after hairdressing and childcare, hospitality has the highest proportion of jobs that are paid below the minimum wage rate at $3.8 \%$ (data refer to April 2016). Similarly, D’Arcy (2017) identifies that employees in Retail and Hospitality have in fact benefitted disproportionately from the introduction of the National Living Wage (NLW) because of these sectors' reliance on employing people at the wage floor.

The hospitality sector is a major global employer. Statistics from the UN World Tourism Organisation (2017) propose that one in ten employees globally work in tourism (hospitality comprising one of the key sectors in tourism). In a report compiled for the British Hospitality Association (Ignite Economics, 2017) hospitality is the UK's fourth largest employer accounting for $3.2 \mathrm{~m}$ jobs directly, and a further $2.8 \mathrm{~m}$ indirectly. Nickson (2013) argues however that while the quantity of jobs supplied by the sector is unquestionable, the quality of hospitality work is of concern to policy makers and academics alike.

Concerns about low pay and poor working conditions in hospitality are not new (e.g.Riley, 1996; Tomoda, 1983). Levels of staff turnover are high although estimates vary considerably, depending to 
an extent on whether one is a core or peripheral employee (e.g. Walmsley, 2004). Unsurprisingly perhaps, hospitality managers face ongoing challenges recruiting, developing and maintaining a committed workforce (Nickson, 2013; Boella and Goss-Turner, 2013) although it is recognised that for some, employment in the industry is appealing (Partington, 2016; Walmsley, 2015; Nickson, 2013; Baum, 2007), for example for those looking for part-time work, others may be attracted by a glamorous image, or the opportunity to meet and engage with a diverse range of customers. Progression in hospitality can also happen relatively quickly. Nonetheless, despite the proliferation of HR rhetoric to the contrary concerns surrounding the employment relationship in tourism and hospitality persist (Baum, 2018)

Crucially, this study explores reactions to the introduction of the NLW, which needs to be distinguished from the Real Living Wage, the latter being entirely voluntary, the former legally binding. As a policy response to the issue of low wages in the UK the Government introduced a mandatory NLW which was implemented in April 2016. This effectively constituted an increase in the minimum wage and the largest fall in low pay in four decades (D'Arcy, 2017). It currently stands (for those 25 years and over) at $£ 7.83$. The Real Living Wage, on the other hand, as calculated by the Living Wage Foundation is currently $f 8.75$. Although some research exists on the uptake of the Real Living Wage (e.g. Werner \& Lim, 2017 who focus on the retail sector) this is, to the authors' knowledge, the first study that explores the hospitality sector's responses to the lower NLW, and further that seeks then to assess what these responses mean for the employment relationship. This, we would argue, is timely given mounting concerns about the business-society relationship (Chang, 2011; Fotaki \& Frasad, 2015; Küng, 2010; Wolff, 2016), especially surrounding the distribution of benefits from economic growth. It seeks therefore to address two research questions:

a) How is the hospitality sector responding to the introduction of the national living wage?

b) What do responses to the introduction of the NLW tell us about the status of the employment relationship in hospitality? 
The paper is structured as follows: The review of the literature sets the introduction of the NLW within its socio-political context, before making reference to previous research on the introduction of minimum wages generally, but also then specifically in the hospitality industry. The literature review concludes with a brief review of employee relations in hospitality. The methodology explains how data were collected, making a case for the interpretive approach adopted as well as discussing how data were analysed. The discussion of the findings is separated into two broad sections, firstly, an overview of responses to the NLW for the individual business, for the sector and then also for the economy, and secondly, a review of what this means for the status of employee relations in hospitality. The paper concludes by summarising key findings as well as providing avenues for future research.

\section{Literature review}

The exchange of labour for a wage is a fundamental feature of labour economics (Sapsford and Tzannatos, 1993; Smith, 2003); this exchange continues to lie at the heart of the employment relationship and indeed is frequently regarded as a defining feature of work itself (see for example Grint, 1991). Assessed on the basis of real wage levels the employment relationship in the UK is strained. Recent years have seen real wages in the UK fall for many, particularly those at the lower end of the wage spectrum. The Resolution Foundation has also claimed that this decade is set to be the worst in over 200 years for pay packets in the UK with latest official forecasts suggesting the average UK worker will still earn less in 2021 than they did in 2008 (O'Connor, 2017).

The National Minimum Wage (Amendment) Regulations 2016 came into force on 1 April 2016 raising the hourly wage rate further to $£ 7.20$ for those aged over 25 . According to Office for National Statistics (ONS) estimates, there were almost four hundred thousand jobs with pay less than the National Living Wage (NLW) held by employees aged 16 and over in April 2016, which constituted $1.3 \%$ of UK employee jobs. This de facto increase in the minimum wage was billed as a NLW by the then Conservative government. It is lower than the (Real) Living Wage which was introduced by the 
Living Wage Foundation in 2004, a rate that is independently calculated based on the actual cost of living; it is not enforceable by law. The Living Wage Foundation encourages employers to pay wages that meets the costs of living rather than just the government minimum wage [https://www.livingwage.org.uk/]. According to Markit (2017) 21\% of all employee jobs paid less than the Living Wage in 2017 , with bar staff (86\%) and waiters and waitresses (83\%) most likely to be paid less.

Literature on the impact of minimum wage legislation at a macro-economic level is neither new (e.g. Mincer, 1976) nor uncommon (e.g.Adams \& Neumark, 2005; Ahn, 2011; Card \& Krueger, 1994; Katz \& Krueger, 1992). Less research exists however on the impact of minimum wage legislation at a micro level. A UK study that looked into the potential impact of the introduction of the NLW (CIPD, 2015) found that $30 \%$ of firms planned to increase productivity, 'taking lower profits/absorbing costs' was the next most popular response (22\%) followed by a reduction in overtime and bonuses $(16 \%)$, raising prices $(15 \%)$ and a reduction in the number of employees (15\%). Fewer than one in ten employers said they would implement one or more of the following: reduce the basic pay growth rate, reduce hours, hire more workers under 25 , hire more apprentices, or cancel/scale down plans for investing in or expanding the business. A further impact concerned a reduction in pay differentials between those affected and their supervisors/managers. Nonetheless, $20 \%$ of employers said they would maintain pay differentials resulting in a 'ripple effect' (this refers to wage rises above the level of the minimum wage that are indirectly caused by uprating of the minimum wage, (Brown, 2017; Grimshaw et al. 2014). Earlier work on the impact of the introduction of NMW on small firms by Ram et al. (2001) also found that the NMW has led to productivity-driven approach as firms were trying to manage labour more efficiently. However, they worryingly concluded in their study that "...the NMW sharpened the divide between formal and informal sectors of the economy", hence small firms were making “...explicit decision of whether or not to go off the books" (p. 858). 
Positive effects of the NLW at the level of the individual firm are equally rarely reported. A case can be made that staff will be more motivated and that productivity will increase due to higher wages (Brown, 2017), but the relationship between wage levels and proximal outcomes (e.g. motivation, staff satisfaction) as well as distal outcomes (e.g. customer satisfaction, profit) is complex (Armstrong, 2009; Price, 2007).

In hospitality specifically, the trade press continues to provide much coverage of what was undoubtedly one of the key concerns for UK hoteliers in 2016 (Ducker, 2016). Within this literature, we find that an increase in prices is something that has been proposed by a number of hospitality firms such as Mitchells and Butlers (Witts, 2015b), Whitbread (Witts, 2015c) and Best Western (Witts, 2015a) as a response to the introduction of the NLW. Some hospitality organisations had decided to introduce the Real Living Wage prior to the introduction of the NLW, e.g. Faucet Inns in 2012, and others such as French bakery and café group Paul introduced the NLW early (November 2015):

Reflecting on human resources management in the tourism and hospitality sectors, Baum (2007) suggests we are still waiting for change, despite at least two decades of literature extolling the importance of employees to business success, a view largely unchanged in a more recent review (Baum, 2018). We argue therefore that a more fundamental view on the nature of employment relations is required to understand and subsequently improve the working lives of hospitality workers. Based on the foregoing discussion, what we know is that a range of potential responses to the NLW exists. What we do not know is how hospitality employers view the introduction of the legislation and what we can infer from this with regard to the employment relationship in hospitality.

\section{Methodology}

The data used in this study derive from twelve semi-structured, in-depth interviews with senior managers in the hotel sector. These data provide on the one hand 'hard facts' in terms of measures 
undertaken to adapt to the legislation, as well as the source of rich, socially constructed data defining the employment relationship. Despite the proliferation of recent studies in hospitality that focus on CSR (e.g. Kim, Rhou, Uysal, \& Kwon, 2017; Kim, Song, \& Lee, 2016), an ideographic and micro-level analysis of managers' beliefs and attitudes remains wholly absent, but we would argue essential in offering rich insights and new understandings (Patton, 1990) as well as a high level of ecological validity (Saunders et al. 2016a).

Sampling was purposive in that all participants needed to be senior managers within UK hotels, but also reflected a convenience sample whereby the researchers followed up personal leads. Although Alvesson and Ashcraft (2012) warn against relying on participants to whom researchers have ready access, because of the potentially controversial nature of the issue at hand, the research team were reliant on accessing participants with whom some prior connection already existed, or who had been recommended by others. The number of participants in studies using qualitative interviews will be contingent, as Saunders and Townsend, 2016b, suggest, on characteristics of the population from which they are chosen. We encountered a general reluctance to participate which we can only surmise relates to the busy schedules, especially given the level of seniority of participants (see Table 1), as well as the topic of the study. In fact, Not only was non-response common, but even when individuals initially agreed to participate, follow-up calls or emails frequently remained unanswered - as outlined, this is a contentious topic and so reluctance to discuss it should not be surprising. Consequently, although the study makes no claims of statistical generalisability, and is essentially exploratory in nature, it is recognised that the sample of hotels included was dominated by mid and up-market businesses (no budget hotels are represented). Nonetheless, in most qualitative studies a balance is struck between representativeness and quality of responses (Alvesson \& Ashcraft, 2012). Thus, given the seniority of participants, it is felt the study was able to gain valuable data and insights into the consequences of this new legislation and, crucially, the employment relationship in hospitality. This is the only study, to the authors' knowledge, that has to date sought a qualitative (rather than survey) approach to assess the impact of the introduction of 
the NLW in hospitality, the gathering of data that can help make sense of complex organizational realities (Eby, Hurst and Butts, 2009, cited in Saunders and Townsend, 2016b:837).

The sample included two directors of major UK hospitality associations whose responses have been included in the analysis because they frequently offered a counterpoint view as to the legislation (the research team also initially sought feedback from employees but only one employer agreed to this and so this was not pursued further). As the researchers were based across the UK the results reflect a variety of geographical locations although there was a preponderance of businesses in the North West and in the South West (eight out of twelve interviewees were based in either of these two regions).

The majority of interviews were conducted in April 2016 (the month the legislation was implemented), the remainder in May. Where possible (in eight out of twelve cases) interviews were conducted face-to-face to facilitate rapport and engagement (Wengraf, 2001). However, given distances, and in one case time constraints, the remainder of the interviews were conducted over the phone. In relation to interview structure, the intention was to pursue key themes developed in the literature review while also allowing for a relatively free conversational flow (Burgess, 1984). Interviews lasted between twenty-five and seventy minutes. Interviews were recorded and subsequently transcribed, then transferred to the qualitative data analysis software Nvivo for further analysis.

The data were analysed in a number of stages. After data familiarisation a first round of coding was undertaken based on an agreed coding scheme which was aligned with the interview schedule, itself drawing on the aims of the study and the literature review. The five key sections of the interview were a) baseline data on the participants and their businesses (descriptive coding: Richards, 2005), b) perceptions of context, c) perceptions of impact, d) measures envisaged as a result of the NLW legislation and finally, e) the employer-employee relationship (all of these being examples of topic coding, Richards, 2005). The first round of coding resulted in 25 codes, 8 of which were emergent, 


\section{Results and discussion}

Following an overview of participants and their businesses (Table 1) the results are presented in two parts based around the two research questions, namely: "How is the hospitality sector responding to the introduction of the national living wage?", and "What do responses to the introduction of the NLW tell us about the status of the employment relationship in hospitality?"

Columns ' $D$ ' and ' $E$ ' in Table 1 reveal that participants overall had a more positive view on business in the past twelve months compared to the twelve months going forward (Column D scale: $1=$ extremely poor, 10 = exceptionally good; Column E scale: 1 = extremely pessimistic, 10 = extremely optimistic). In fact, overall participants were positive about business in the past twelve months with seven scoring at least an 8 . Scores were lowered slightly for views on business going forward with 
two participants scoring a fairly pessimistic 4 (both of these in the North West). Nonetheless, overall seven participants were still fairly optimistic for business prospects, scoring 8-9.

INSERT TABLE 1 HERE

Impacts and measures taken

As to be expected, all participants mentioned the direct impact on wage costs as a result of the introduction of the NLW. The increase from $f 6.70$ to $f 7.20$ (+7.5\%) followed an earlier $3 \%$ increase in October 2015, that is to say there had been an increase of almost $11 \%$ in the minimum/living wage in one year. Furthermore, some participants expressed concern about further annual increases as the government has set a target for 2020 when the NLW should reach $60 \%$ of the UK median wage. A participant from one of the smaller boutique hotels drew attention to the differential impact of the NLW on this type of hotel. Where the offer was very labour intensive, the impacts would be felt more, affecting 'the dynamics and viability of a smaller country house hotel'. The disproportionate impact on small businesses was something mentioned by a number of participants and is something also considered by Brown (2017).

Indirect effects were also mentioned; foremost here were concerns about staff morale for those who did not benefit, or not benefit as much from the introduction of the NLW (e.g. those under 25 years of age, supervisors who were receiving slightly more than the new minimum wage rate at the outset). Whereas businesses suggested it was too early to tell whether the NLW had had a positive impact on morale and associated variables, e.g. engagement, commitment and productivity the concerns about pay differentials were clear:

'...but you cannot afford to put $10 \%$ up for everybody. However, if you don't do anything different then you'll have a highly motivated frontline team, but highly demotivated managers' (5SW).

'I think the main challenge that we have is to maintain the pay differential...They will be asking questions like '...why should I continue in my role as a supervisor when I only get back $5 p$ an hour more than other staff?' (8NW). 
Participants were also asked what the NLW would mean for the hotel sector and the wider economy. Answers to both questions varied somewhat and were more tentative with regard to implications for the economy. Here the general verdict was split. On the one hand it was argued consumers would have more money in their pockets which would lead to more spending and in consequence would stimulate the economy. On the other hand it was also suggested that as labour became more expensive this would lead to redundancies as demand for labour fell.

With regard to impacts on the hotel sector specifically, a number of concerns were raised. The structure of the workforce was something frequently mentioned, whether in relation to the increased use of apprentices or young employees in an attempt to reduce payroll costs, or more indirectly through the increased use of migrants (the argument made was that more economic migrants would be attracted to the UK given the increase in wages ${ }^{1}$ ). Other employment-related impacts included an increase in labour productivity, also allied to a reduction in staff, and an increased use of casual contracts. The intensification of labour, as well as a more efficient management of labour as a response to the introduction of a national minimum wage in the UK was recognised by Ram et al. (2001) in an earlier study on small firms. It was also argued that the sector would now be in a better position to compete with other sectors for talented individuals, and that the increased pressures on business might lead to enhanced strategic thinking. In fact, one of the hospitality association representatives mentioned directly his hope that these added pressures would lead to a more strategic approach to business, specifically with regard to HRM. A certain amount of frustration was evident in this participant's comments that the hospitality sector was still not taking a strategic approach to HRM (e.g. in relation to recruitment, selection, training and career progression). As was acknowledged previously, employee relations in hospitality generally tend to be regarded as weak and there appears to be scope, certainly according to this participant, for a more strategic approach to HRM in the sector.

\footnotetext{
${ }^{1}$ This argument has now been turned on its head given the, at the time of writing at least, substantial fall in the value of the pound and given the uncertainty as a result of the UK's BREXIT vote in June 2016.
} 
With respect to businesses' reaction to changes in wage legislation specifically, an earlier study on the introduction of the minimum wage by Arrowsmith et al. (2003: 452) suggested that '...the NMW did not provide a shock sufficient to jolt employers or workers out of their customary practices and habits', hence businesses just reacted in a more ad-hoc manner. Traditional thinking has it that the hospitality industry tends to be managed less strategically and in a more ad-hoc style (Gilman et al., 2002; Lucas \& Langlois, 2001) which might suggest reactions to the NLW are equally ad hoc. However, some studies reveal more strategic behaviour particularly among hoteliers (Brown \& Crossman, 2000; Hoque, 1999) pointing to a more considered response to wage legislation. In the main, businesses that participated in this study adopted what we term a 'half-way house' approach, being neither entirely spontaneous in their responses, nor demonstrating significant longer term shifts in strategic thinking with regard to employment. To an extent, because the majority of businesses were part of hotel chains, or at least a small group of hotels, some strategic direction was provided centrally. It is recognised that had the sample included smaller, independent establishments the outcome in this regard may have been different. Specifically, it is generally understood that levels of formality grow with firm size (Churchill and Lewis, 1983; Messeghem, 2003). Past studies examining the impact of the NMW on small firms found that the informality of employee relations helped mediate the impact and created a general benign impact on these firms (Arrowsmith et al., 2003; Edwards et al. 2004). Given lower levels of formality, had the sample included a greater proportion of small firms, we might have expected therefore to have seen greater levels of ad-hoc arrangements governing the response to the NLW.

Understandably, businesses were concerned how any price rise might affect demand and so a more common stance was to offset the increase in salaries via an increase in sales volume:

'At the moment we are just trying to find more business to cover that cost. We are not increasing or passing that cost on to the customer neither decrease staff levels because of the increased costs. We 
are just looking for more volume at the moment, so increase covers at the restaurant, increase occupancy in the rooms, so to increase business level which helps absorb a little bit of that' (9NW).

An additional theme raised by participants related to the potential to increase productivity, at the same time as growing sales. This growth in sales would allow the maintenance of staffing levels, rather than a reduction although some businesses mentioned the imposition of recruitment freezes. The intensification of work in hospitality as a result of the introduction of the minimum wage has also been identified previously (Ram et al. 2001).

The measures businesses were taking to offset the impact of the NLW reflected the extent to which they were concerned, or at least voiced concern, about it. Some managers were quite philosophical in their outlook:

'We all have increases [in costs] from time to time that might be unexpected and new. We all have approved budgets for this year... So it wasn't a major surprise... Most people will find a clever way to absorb the cost. I think owners now say that normally this time of the year we had $7 \%$ or $8 \%$ growth but now... it will go $6 \%$. I think that's what most of the people have done' (8NW).

Whereas for other businesses, the level of concern was arguably higher as demonstrated by measures taken:

'...we have been really deepening down on every single process review, so the micro details, so for example we're taking the linen out of a couple of the fine dining restaurants, and it's not the linen it's the fact that I've got people on a Saturday night spending half an hour ironing linen, I've got linen porters carrying it from one point to another, and I'm physically getting down to how can I save a repetitive 10 minutes here, or a repetitive 16 minutes there' (4SE).

Or, to provide another pertinent quote: 
'We do look at the efficiency for example how many hours you need for this task, and to be a bit more efficient. But we don't want the service to suffer...you don't want to cut hours and this is why we look at waste, energy, maintain the equipment. So, for example, last year we may have broken 20 plates and we may not have enough to serve people. We have to buy new now. But now all these things matter and they didn't used to' (7NW).

The reactions of these two firms should be seen in light of their trading outlook which was relatively pessimistic (see Table 1). To conclude, we draw attention to the view of one of the representatives of the hospitality associations in that in their opinion too many hotels are looking to minimise costs as opposed to thinking about how HR strategies might be changed. Rather than seeing the introduction of the NLW as an impetus to overhaul HR strategies, thereby tackling the perennial issues of high levels of labour turnover and low levels of productivity with implications also for quality, the sector is continuing to rely on staid employment practices:

'Some of them are very proactively looking at how they do maximise the logistics and stuff, others are just beginning to get their heads round in terms of what they might need, and then looking at cost reductions rather than necessarily looking strategically to say "Ok, we might need to think of this and therefore change our whole people strategy as a company"'.

\section{The NLW and the employment relationship}

This section tackles the second question of the study, what responses to the introduction of the NLW tell us about the status of the employment relationship in hospitality? The exchange of labour for a wage lies at the heart of traditional conceptions of employment, and so how employers view the introduction of the NLW should offer insights into the foundation of employment relations in the sector. The starting point was the question as to whether participants agreed with the introduction of the NLW. All participants answered in the affirmative. This arguably socially desirable response might have been expected, and yet delving deeper it was clear that the extent of agreement varied. Further analysis pointed to a (moral) dilemma, or at least a conflict of interests between employees, 
the business and the manager. Participants, as agents of the firm, were caught between personal values and acting on behalf of the firm. The need for higher salaries was recognised but simultaneously profits should not be jeopardised (in part at least out of self-interest, also where performance related to individual rewards), although interestingly very few participants acknowledged this dilemma directly. Only one participant addressed the issue explicitly, conceding that lower profits might need to be accepted to provide for more just rewards for employees:

'I'd say this, if our company made, let's throw a number out there and say half a million pounds last year, because of increasing everyone to the National Living Wage, if we only therefore made $£ 450,000$, isn't that better?' (2SW)

These results are at one aligned with Werner and Lim's (2017) study of SMEs in retail in relation to owner/managers' agreement with paying a living wage, but they also differ for some in the sample here, not owners but managers, who also had to consider corporate interests. Where at a personal level participants appreciated the need for the NLW, its implications were not necessarily welcomed. Participants were then also asked about hospitality's purportedly negative image as an employer. While many agreed with this notion, citing the common themes of low pay, long, anti-social and irregular hours, others argued that it was solely certain jobs that suffered from a poor image (notably chefs). Sometimes the downsides of working in the sector were contrasted with the benefits, suggesting a trade-off was taking place:

'Ultimately the industry is hard work with long and unsociable hours however I think that what the industry deals with is the celebration of the good things... There is a lot to celebrate but I think that people focus very much on the narrow aspects of the hard work and the unsociable hours and potentially of the low pay' (8NW). 
'It has an image problem because it's perceived as one of the lower paid service sectors, but I think that what people don't balance out is the benefits people get working in the hospitality sector' (2SW - benefits mentioned included free staff meals, use of gym facilities, discounts at sister properties).

While this trade-off stance has some initial face validity, and indeed supports notions of positive views of employment in the sector (Nickson 2013; Walmsley, 2015), some aspects of work (e.g. worker organisation, holiday entitlements) are so important they are enshrined in law or at least promoted by international bodies such as the International Labour Office's Declaration on Fundamental Principles and Rights at Work. These are issues that cannot simply be 'traded in'. Akin to reactions to the NLW, there was then acknowledgement of an employment problem in the sector (low wages, poor working conditions), but then also some apologist language justifying the status quo.

Exchange forms the basis of traditional economics, in the market for goods as well as for labour. Reactions to the NLW will reflect how employers view this exchange; what they are providing in exchange for what the employee is providing/should be providing. The final part of the interview therefore asked about the responsibilities of employers to employees and vice versa.

Answers to the question as to the responsibilities of an employer to employees varied considerably indicating a lack of a common understanding to what is a fundamental question in discussions of hospitality business practices. The overall impression gained, was that the question itself had never been considered, certainly not in any depth. Responses to the question of the responsibility of employers to employees varied. Some participants provided examples of actions undertaken, e.g. providing training and career progression opportunities, avoiding employees having to do split shifts. One participant spoke about providing vouchers, free stays and special lunches. Others stated very fundamental responsibilities such as providing a safe working environment and job security. Again, others took things a step further and commented on providing a decent working environment but also the need to consider the employee's future. The notion of work-life balance arose in four 
interviews. Overall the participants of this study did, judging by what they were saying, care about and look after their employees. As mentioned in the methodology, by dint of the fact that they had agreed to speak to us this is unlikely to be an entirely representative sample of hoteliers. Even more telling is this general lack of philosophical consciousness surrounding the employment relationship and by implication what role firms should play in society. One participant reflected very directly on this:

'The difficulty for me is that I work for an organization that values training and development, and career growth is something that we have always done. But I'm mindful that there are a lot of organizations out there who do not necessarily have the same philosophy that we have and don't focus on fairness on pay, training and development and providing career opportunities,' (8NW).

We conclude the discussion with an overview of responses to the question of an employee's responsibility to the employer. Overall, there was greater conformity in the answers to this question than to the previous one. Most respondents commented on loyalty, commitment and dedication to the job. A selection of quotations serves to illustrate:

'So, what do we expect from our employees? We want commitment, dedication, we don't want them just turning up, we want the passion, a drive, we want to see them wishing to deliver the very best service, and ensuring that our guests are always happy,' (1SW).

'I think just giving 100\%,' (5SW).

'Work hard and be loyal and do your best every day. And that's as simple as that really,' (8NW).

These views conform with Boella and Goss-Turner's position (2013:44) who point out: “Even today...many employers and managers expect all employees, whatever their position and wage rate, to be dedicated to their jobs, to have a vocational fervour towards their work and to sacrifice leisure time for pay that is not high...". Some respondents highlighted the transactional nature of the 
employment relationship. Thus, one participant spoke of a contract between employer and employee, another participant talked about both sides needing to fulfil their side of the bargain:

'We expect quite a lot from our employees. And they've got a good environment to work in, they've got the potential, a lot of opportunities are going forward. We expect a lot but we also give a lot,' (9NW).

'A lot' was described here as: being professional, meeting standards (especially in relation to service quality), adopting a collaborative/team-working approach, along with the acknowledgement that all staff were subjected to rigorous performance appraisals. In relation to the employer 'giving a lot' this covered 'a good environment to work in' and 'a lot of opportunities'. We note though that fitting financial remuneration was not mentioned under the rubric of 'giving a lot'.

We can summarise that the question of responsibility of employers to employees and vice versa produced a great variation in responses; more so in relation to the responsibility of the employer to the employee which appears to have been less considered than the question of the employees' responsibility to the employer. As has been outlined, these are issues of fundamental importance to the employment relationship, industrial relations and ultimately the relationship between hospitality businesses and society.

\section{Conclusion}

This study has explored reactions to the introduction of a national living wage in the UK hospitality industry, a sector heavily reliant on low paid workers (D'Arcy, 2017; ONS, 2016), where working conditions are traditionally regarded as poor (Baum, 2007; Wood, 1997), and employment relations weak (Lucas, 2004). It reviewed responses of hospitality managers to the introduction of the NLW, and also what their response means for the employment relationship in hospitality more generally.

All employers agreed that, in principle, the NLW was a good thing, but beyond this a range of positive and negative reactions were evident. Concerns were raised specifically about the ability of 
smaller and more labour intensive (high-end/boutique) businesses to deal with increases in the NLW. Furthermore, and possibly counter-intuitively, the NLW has the potential to decrease productivity where sudden changes to pay differentials that are regarded as unfair negatively affect staff morale. This may occur, for example, where younger staff (under 25s) are not entitled to the same wage, or where supervisors see the pay differential between their wages and those of subordinates narrow.

The positive implications of the NLW largely circled around increases in disposable income, the negative on redundancies and increased use of flexible employment contracts. A greater employment of youth (i.e. younger than 25 ) was also suggested by some in a sector where youth employment, and the employment of marginalised groups more generally, is already very common (Walmsley, 2015). The potential substitution of young for older workers to exploit lower-level youth minimum wages has already been recognised by Croucher and White (2010) and Brown (2017), an issue mirrored in this study. In a pre-Brexit Referendum Britain, only one participant reflected on the implications for the employment of migrant workers, arguing a higher minimum wage would make the UK a more attractive destination for economic migrants. A possible outcome of the UK's withdrawal from the EU could be an improvement in working conditions in hospitality to make it more appealing to UK workers (D'Arcy, 2017).

As is typical for the sector (Gilman et al., 2002; Lucas \& Langlois, 2001), businesses were neither particularly strategic, nor entirely reactive in their approaches to dealing with the NLW. Adaptive measures to the NLW varied from businesses taking a very detailed, labour process oriented approach at reducing costs, to others that recognised the potential impact but did not appear too concerned by it. No common approach was discernible, and a range of adaptive measures were mentioned, such as price increases, increasing unit sales, cutting costs elsewhere including staff reductions/recruitment freezes as well as the subsequent increases in productivity. In light of the view that increases in the price of labour will result in a fall in demand for labour, this micro-level 
analysis offers some evidence to support this position in the short term. Rather than see an increase in wages akin to an investment in a capital asset (Wright et al., 1994) and as recommended by one of the hotel association representatives, the broader response was to regard wage increases as an increase in the costs of labour.

These responses, in particular the ambivalence expressed towards the NLW, raise questions about the employment relationship in hospitality, and indeed by extension into the business-society relationship as seen through the eyes of senior industry managers. While all participants were certainly concerned about their employees' welfare, and supported the NLW in principle, it was also clear that personal beliefs collided with business imperatives. The study confirms Wood's (1991) conceptualisation of CSR as occurring at three distinct levels: institutional, organizational and individual: there is some evidence that personal beliefs conflicted with organisational values.

This study sets the scene for further research, with implications for practice. Firstly, this study has demonstrated that among hospitality employers confusion exists with regard to what the responsibilities of a business should be in relation to its employees. The exchange of wages for labour that lies at the heart of traditional economics is an exchange with 'fuzzy boundaries'. It is an issue that had received very little consideration at this fundamental level by participants, and yet is arguably one that is fundamental in shaping employment relations. A lack of consideration of this question explains how comments suggesting employees should 'just give 100 percent' or that they should 'be loyal and do their best every day' could be made within the context of the introduction of a national living wage, a wage that allows employees and their families to just get by (or in fact is insufficient for these purposes as argued by the Living Wage Foundation).

Secondly, further studies could explore if and how societal changes such as growing levels of inequality and concerns about globalisation are changing the way hospitality firms do business. For example, while it is interesting to note that an increasing number of prospective employees consider hospitality employers' corporate social performance when seeking employment (Kim et al., 2017), 
the extent to which this applies to those at the lower end of the wage spectrum, which constitutes a large proportion of hospitality employees, is questionable. Being able to choose one's employer is a luxury many can ill afford (Colling \& Terry, 2010), which leaves the opportunity for exploitation of an unequal employment relationship open. It remains to be seen to what extent the coming decade will see a 'business as usual' approach to employment in hospitality, or whether the introduction of a NLW is the start of a wider debate on the nature of employment relations, and a revisit of the question 'for whom should corporations be run?' (Blair, 1998).

Finally, we acknowledge the limits to generalisability in the study given the small sample size.

Because of the sensitive nature of the topic a small number of participants, all at senior levels within their respective organisations, was perhaps to be expected. Furthermore, in keeping with its exploratory nature the study has been able to surface a diverse range of reactions to and implications of the NLW upon which further research might usefully build. Future research could extend this study by focussing on a broader range of sub-sectors of hospitality (e.g. restaurants, cafes, contract caterers), for example, or gather insights from hospitality employees at various levels within organisational hierarchies. While the introduction of the NLW has ameliorated pay for many in hospitality, as D'Arcy (2017:8) acknowledges "much more will be needed to improve the prospects and day-to-day work of those in low-paying jobs".

\section{References:}

Adams, S. and Neumark, D. (2005), "The effects of living wage laws: Evidence fromfailed and derailed living wage campaigns", Journal of Urban Economics, Vol. 58 No. 2, pp. 177-202.

Ahn, T. (2011), "Distributional impacts of a local living wage increase with ability sorting", Economic Letters, Vol. 112, pp. 283-286.

Alvesson, M. and Ashcraft, K. L. (2012), "Interviews", in Symon, G. and Casslee, C. (Eds.), Qualitative Organizational Research: Core Methods and Current Challenges. Sage, London, pp. 239-257. Armstrong, M. (2009), Armstrong's Handbook of Performance Management. An evidence-based guide to delivering high performance (4th Edition), Kogan Page, London.Arrowsmith, J., Gilman, M. W., Edwards, P., \& Ram, M. (2003), "The Impact of the National Minimum Wage in small firms". British Journal of Industrial Relations, Vol. 41 No. 3, pp. 435-456.

Baum, T. (2007), "Human resources in tourism: Still waiting for change", Tourism Management, Vol. 28 No. 6, pp. 1383-1399. 
Baum, T. (2018), "Sustainable human resource management as a driver in tourism policy and planning: a serious sin of omission?", Journal of Sustainable Tourism. Available online: 26 January 2018. http://www.tandfonline.com/doi/full/10.1080/09669582.2017.1423318

Blair, M. (1998), "For Whom Should Corporations Be Run?: An Economic Rationale for Stakeholder Management", Long Range Planning, Vol. 31 No. 2, pp. 195-200.

Boella, M., and Goss-Turner, J. (2013). Human Resource Management in the Hospitality Industry. A Guide to Best Practice. Taylor and Francis, London.

Brown, D. and Crossman, A. (2000), "Employer strategies in the face of a national minimum wage: an analysis of the hotel sector. ", Industrial Relations Journal, Vol. 31 No. 3, pp. 206-219.

Brown, W. (2017), "The toxic politicising of the National Minimum Wage", Employee Relations, Vol. 39 No. 6, pp. 785-789.

Burgess, R. G. (1984), In the field: An Introduction to Field Research., Hadwin, London.

Card, D. and Krueger, A. (1994), "Minimum Wages and Employment: A Case Study of the Fast-Food Industry in New Jersey and Pennsylvania", The American Economic Review, Vol. 84 No. 4, pp. 772-793.

Chang, H.-J. (2011), 23 Things They Don't Tell You About Capitalism, Penguin Books, London.

Churchill, N., and Lewis, V. (1983). "The five stages of small business growth.", Harvard Business Review, Vol. 83 No. 61, pp.30-50.

CIPD. (2015), "Half of all employers expect to be affected by the new National Living Wage", in. Chartered Institute of Personnel Development, London

Colling, T. and Terry, M. (2010), "Work, The Employment Relationship and the Field of Industrial Relations", in Colling, T. and Terry, M. (Eds.), Industrial Relations Theory and Practice. John Wiley and Sons, Chichester, pp. 3-27.

Croucher, T. and White, G. (2010), "The Impact of Minimum Wages on the Youth Labour Market: An International Literature Review.", in. Low Pay Commission, London.

D'Arcy, Connor. (2017) Low Pay Britain. Resolution Foundation, 2017. https://www.resolutionfoundation.org/app/uploads/2017/10/Low-Pay-Britain-2017.pdf

Ducker, P. (2016), Keynote Address, Plymouth University Hotel School Patron's Conference, 29.01.2016 Plymouth University, Plymouth.

Eby, L. T., Hurst, C. S., and Butts, M. M. (2009). Qualitative research: the redheaded stepchild in organisational and social science research. In C. E. Lance \& R. J. Vandenberg (Eds.), Statistical and Methodological Myths and Urban Legends: Doctrine, Verity and Fable in Organisational and Social Sciences. Routledge, New York, pp. 219-246.

Edwards, P., Ram, M. and Black, J. (2004) "Why does employment legislation not damage small firms?". Journal of Law and Society, Vol. 31, No. 2, pp. 245-265.

Fotaki, M. and Frasad, A. (2015), "Questioning Neoliberal Capitalism and Economic Inequality in Business Schools", Academy of Management Learning and Education, Vol. 14 No. 4, pp. 556575.

Gilman, M., Edwards, P., Ram, M. and Arrowsmith, J. (2002), "Pay determination in small firms in the UK: the case of the response to the National Minimum Wage", Industrial Relations Journal, Vol. 33 No. 1, pp. 52-67.

Grimshaw, D., Bosch, G. and Rubery, J. (2014), "MinimumWages and Collective Bargaining: What Types of Pay Bargaining Can Foster Positive Pay Equity Outcomes?", British Journal of Industrial Relations, Vol. 52 No. 3, pp. 470-498.

Grint, K. (1991), The Sociology of Work. An Introduction, Polity Press, Cambridge. 
Hoque, K. (1999), "New approaches to HRM in the UK hotel industry", Human Resource Management Journal, Vol. 9 No. 2, pp. 64-76.

Ignite Economics. (2017), The Economic Contribution of the UK Hospitality Industry, British Hospitality Association, London.

Jones, P. (2002). Introduction to Hospitality Operations. An Indispensable Guide to the Industry (2 ${ }^{\text {nd }}$ Edition), Continuum, London.

Katz, L. F. and Krueger, A. B. (1992), "The effect of the minimum wage on the fast-food industry", Industrial and Labor Relations Review, Vol. 46 No. 1, pp. 6-21.

Kim, H. L., Rhou, Y., Uysal, M. and Kwon, N. (2017), "An examination of the links between corporate social responsibility (CSR) and its internal consequences", International Journal of Hospitality Management, Vol. 61 No. in progress, pp. 26-34.

Kim, J., Song, H. and Lee, C.-K. (2016), "Effects of corporate social responsibility and internal marketing on organizational commitment and turnover intentions", International Journal of Hospitality Management, Vol. 55, pp. 25-32.

Küng, H. (2010), Anständig wirtschaften: Warum Ökonomie Moral braucht, Piper Verlag GmbH, München.

Lucas, R. (2004), Employment Relations in the Hospitality and Tourism Industries, Routledge, London.

Lucas, R. and Langlois, S. M. (2001), "The National Minimum Wage: What Can Young Workers Tell Us? Report for the Low Pay Commission. ", in. CHER, Manchester Metropolitan University, Manchester.

Markit. (2017) Living Wage Research for KPMG. Henley on Thames: IHS Markit. https://assets.kpmg.com/content/dam/kpmg/uk/pdf/2017/11/kpmg-living-wage-research2017.pdf

Messeghem, K. (2003), "Strategic entrepreneurship and managerial activities in Smes", International Small Business Journal, Vol. 21 No. 2, pp.197-212.

Mincer, J. (1976), "Unemployment effects of minimum wages", Journal of Political Economy, Vol. 84 No. 4, pp. 87-104.

Nickson, D. (2013). Human Resource Management for the Hospitality and Tourism Industries (2nd Edition). London: Routledge.

O'Connor, S. (2017), "UK real wages drop for first time in three years", Financial Times, 17 May 2017. https://www.ft.com/content/aa299754-3ae0-11e7-821a-6027b8a20f23?mhq5j=e1

Office for National Statistics. (2016) Statistical Bulletin: Low Pay in the UK: Apr 2016, by Office for National Statistics.

https://www.ons.gov.uk/employmentandlabourmarket/peopleinwork/earningsandworkingh ours/bulletins/lowpay/apr2016\#low-pay-by-industry

Partington, S.N. (2016), Hospitality Employment: The Good, The Bad and The Ugly, in Lashley, C. (Ed.), The Routledge Handbook of Hospitality Studies, Routledge/Taylor \& Francis Group, Oxford, pp. 207-219

Patton, M. (1990), Qualitative Evaluation and Research Methods, Sage, Newbury Park.

Pond, C. (1983), "Wages Councils, The Unorganised and the Low Paid", in Bain, G. S. (Ed.), Industrial Relations in Britain. Basil Blackwell, Oxford, pp. 179-208.

Price, A. (2007), Human Resource Management in a Business Context, Thomson Learning, London

Prowse, P. and Fells, R. (2016), "The Living Wage - policy and practice", Industrial Relations Journal, Vol. 47 No. 2, pp. 144-162.

Ram, M., Edwards, P.,Gilman, M. and Arrowsmith, J. (2001), "The dynamics of informality: employment relations in small firms and the effects of regulatory change". Work, Employment and Society, Vol. 15 No. 4, pp. 845-861. 
Richards, L. (2005), Handling Qualitative Data. A Practical Guide., SAGE Publications, London.

Riley, M. (1996), Human Resource Management in the Hospitality and Tourism Industry, Butterworth-Heinemann, Oxford.

Saunders, M., Lewis, P. and Thornhill, A. (2016a), Research Methods for Business Students, Pearson, Harlow.

Saunders, M., and Townsend, K. (2016b), "Reporting and justifying the number of interview participants in organization and workplace research", British Journal of Management, Vol. 27 No.4, 836-852.

Tomoda, S. (1983), "Working conditions in the hotel, restaurant and catering sector: a case study of Japan", International Labour Review, Vol. 122 No. 2, pp. 239-252.

United Nations World Tourism Organisation. (2017). UNWTO Tourism Highlights 2017 Edition. Madrid: UNWTO.

Walmsley, A. (2004). Assessing staff turnover: a view from the English Riviera. International Journal of Tourism Research, Vol. 6 No.4, 275-287.

Walmsley, A. (2015), Youth Employment in Tourism. A Critical Review, Goodfellows, Oxford.

Wengraf, T. (2001), Qualitative Research Interviewing. Biographic Narrative and Semi-Structured Methods, SAGE Publications, London.

Werner, A. and Lim, M. (2017), "A new living contract: cases in the implementation of the Living Wage by British SME retailers", Employee Relations, Vol. 39 No. 6, pp. 850-862.

Witts, S. (2015a), "Best Western Warns of Price Rises and Job Cuts to Combat Living Wage", in Big Hospitality. http://www.bighospitality.co.uk/Business/Best-Western-warns-of-price-risesand-job-cuts-to-combat-LivingWage?utm_source=copyright\&utm_medium=OnSite\&utm_campaign=copyright

Witts, S. (2015b), "Diners Will Pay the Price for the Living Wage, Mitchells and Butlers Warns", in Big Hospitality. http://www.bighospitality.co.uk/Business/Diners-will-pay-the-price-for-theLiving-Wage-Mitchells-Butlerswarns?utm_source=copyright\&utm_medium=OnSite\&utm_campaign=copyright

Witts, S. (2015c), "Whitbread to Raise Prices to Combat Cost of National Living Wage", in Big Hospitality. http://www.bighospitality.co.uk/Business/Whitbread-to-raise-prices-to-combatcost-of-National-LivingWage?utm_source=copyright\&utm_medium=OnSite\&utm_campaign=copyright

Wolff, R. (2016), Capitalism's Crisis Deepens. Essays on the Global Economic Meltdown, Haymarket Books, Chicago.

Wood, D. (1991), "Corporate social performance revisited", Academy of Management Review, Vol. 16 No. 4, pp. 691-718.

Wood, R. C. (1997), Working in Hotels and Catering, Routledge, London.

Wright, P., McMahan, G. and Williams, A. (1994), "Human resources and sustained competitive advantage: a resource-based perspective", International Journal of Human Resource Management, Vol. 5 No. 2, pp. 301-326. 
2

3

4

5

6

7

8

9

Table 1: Participants and their Businesses

\begin{tabular}{|c|c|c|c|c|c|}
\hline $\begin{array}{l}\text { [A] Key } \\
\text { (SW = } \\
\text { South } \\
\text { West; NW } \\
\text { = North } \\
\text { West; SE = } \\
\text { South } \\
\text { East) }\end{array}$ & [B] Position & [C] Organisation Size & $\begin{array}{l}\text { [D] Business } \\
\text { last } 12 \\
\text { months } \\
\text { (April 2015- } \\
\text { April 2016) }\end{array}$ & $\begin{array}{l}\text { [E] } \\
\text { Business } \\
\text { going } \\
\text { forward } \\
\text { (April 2016- } \\
\text { April 2017) }\end{array}$ & [F] Ownership \\
\hline $15 W$ & GM & $\begin{array}{l}45 \text { employees, } 32 \text { full } \\
\text { time }\end{array}$ & 10 & 8 & $\begin{array}{l}\text { Small chain of } \\
\text { boutique hotels }\end{array}$ \\
\hline $2 S W$ & GM & $\begin{array}{l}165 ; 100 \text { people that } \\
\text { are full or part time, } \\
\text { then } 65 \text { on zero hour } \\
\text { contracts; }\end{array}$ & 9 & 8 & Multinational \\
\hline $35 W$ & GM & 60 FTE; & $7-8$ & $8-9$ & Multinational \\
\hline 4SE & CEO & $\begin{array}{l}750 \text { FTE plus casuals } \\
\text { across a number of } \\
\text { hotels; }\end{array}$ & 6 & 6 & $\begin{array}{l}\text { Small chain of } \\
\text { boutique hotels }\end{array}$ \\
\hline $5 S W$ & GM & 80 FTE; & 8 & $8-9$ & Independent \\
\hline 6NW & $\begin{array}{l}\text { Ops and HR } \\
\text { Manager }\end{array}$ & $\begin{array}{l}\text { Between } 100-200 \text { staff } \\
\text { (approx. } 50 \% \text { on zero } \\
\text { hours contracts }\end{array}$ & 10 & 8 & Multinational \\
\hline $7 N W$ & $\begin{array}{l}\text { Regional HR } \\
\text { Manager }\end{array}$ & $\begin{array}{l}\text { Over } 200 \text { staff } \\
\text { (approximately 55\% } \\
\text { on zero hours } \\
\text { contracts) }\end{array}$ & 10 & 4 & National chain \\
\hline $8 N W$ & $\begin{array}{l}\text { Regional HR } \\
\text { Director }\end{array}$ & $\begin{array}{l}\text { Between } 100-200 \text { staff } \\
\text { in the hotel s/he is } \\
\text { based in (approx. } 40 \% \\
\text { on casual contracts) }\end{array}$ & 9 & $7-8$ & Multinational \\
\hline 9NW & GM & $\begin{array}{l}120 \text { full-timers and } 30 \\
\text { part-timers, a lot of } \\
\text { casuals on top. }\end{array}$ & 6 & 4 & $\begin{array}{l}\text { Luxury hotel, } \\
\text { independent }\end{array}$ \\
\hline $10 S W$ & $\begin{array}{l}\text { Director of } \\
H R\end{array}$ & 120 (85 full time) & 8 & 8 & $\begin{array}{l}\text { Boutique/Luxury } \\
\text { hotel part of a } \\
\text { larger } \\
\text { conglomerate }\end{array}$ \\
\hline
\end{tabular}


1

2

3

4

5

6

7

8

9

10

11

12

13

14

15

16

17

18

19

20

21

22

23

24

25

26

27

28

29

30

31

32

33

34

35

36

37

38

39

40

41

42

43

44

45

46

47

48

49

50

51

52

53

54

55

56

57

58

59

60 